\title{
Quality of Strips at the Longitudinal-wedge Rolling Mill
}

\author{
Mashekov Serik Akimovich ${ }^{1}$, Smaylova Nurgul Temirgalievnaa, ${ }^{2,}$, Smagulova Nazim $\mathrm{K}^{1}$, Mashekova \\ Aygerim Serikovna $^{1}$, Tukibay Asilzat Ahmetkizi ${ }^{1}$
}

${ }^{1}$ K.I. Satpayev Kazakh National University, 050013. Almaty, 22 Satpayev str

${ }^{2}$ S. Toraigyrov Pavlodar state University, Kazakhstan, 140007, Pavlodar, 64 Lomov str

*Corresponding Author: ganibek2006@mail.ru

Copyright (C) 2013 Horizon Research Publishing All rights reserved.

\begin{abstract}
In article influence of temperature and deformation modes of rolling and cooling on regularity of structure formation of the steel, rolled on a new longitudinally maple camp is probed. Cages of a longitudinally maple camp contain working and reference rolls of constant diameter, and in sequentially located cages diameter of working rolls decreases, and diameters of reference rolls increase in the direction of rolling. It is set that it is necessary to make rolling of bands with a temperature of the end of rolling $830-840^{\circ} \mathrm{C}$ and temperature of cooling of the hot-rolled bands on leading-out live rolls $610-650^{\circ} \mathrm{C}$.
\end{abstract}

Keywords Maple Camp, Roll, Temperature and Deformation Modes, Hot-Rolled Bands, Structure

\section{Introduction}

Currently, the most promising direction in the development of production of hot rolled strips is to provide high quality rolled thin $(0.6-2.0 \mathrm{~mm})$, which can be used to replace the more expensive cold-rolled [1-6]. The use of thin hot rolled strips as a tackle in the production of ultra-thin cold-rolled strip, can significantly reduce the cost of the price of the latter (at least 20\%) [1,7]. However, such replacement is possible only when the hot-rolled steel will fully meet several technical requirements, in particular, have a satisfactory level of desired microstructure and mechanical properties.

It is known, that structure of obtained hot-rolled metal product and its mechanical properties directly depend on temperature conditions of rolling and coiling, as well as conditions of strip cooling at the outgoing roller table [1]. Various microstructure of the rolling strip is obtained depending on cooling speed (heat removal intensity), i.e. varying cooling conditions mechanical properties of the roll stock can be modified in a quite wide range.

Enhanced strength properties of the rolled metal are obtained at the increased cooling speed under other equal conditions, whereas some reduction of its plastic properties occurs [1]. However it should be taken in consideration that slightly hardened metal layer formation occurs at the surface of strip at a very high speed. Strip thickness microstructure nonuniformity, obtained at high cooling speeds, hyper-hardness and "fraility" of slightly hardened surface, as a whole, cause incompliance of obtained mechanical properties of hot-rolled products with standard requirements, i.e. rejections.

Therefore, thin strips of hot-rolled microstructure is produced in known mills, often characterized by significant Inequigranular (large grains on the surface), which results when using a metal for cold forming various defects in the formation of [9]. The main cause of assorted thin strips is wrong setting temperature and strain rolling and cooling modes.

Since the hot-rolling mills differ significantly in structure ( the number and location of stands, reels, length, intermediate and outlet roller conveyors, power of the main drive, etc.), the production technology for flat products are even the same product mix varies. Technological solutions that are effective in one of the camp are often unsuitable for another [10]. Therefore, the study of the influence of temperature regimes rolling and coiling and cooling modes bands on the quality of the hot-rolled steel, rolled on the new mill is of great importance.

The purpose of this paper is to investigate the effect of temperature, strain and cooling conditions of rolling on regularity of St3sp strip structure generation, rolled at a new longitudinal-wedge mill.

\section{Materials and Experimental Techniques}

Rolling was carried out at a new designed longitudinal-wedge mill (figure 1) [2]. Distinctive characteristic of the longitudinal-wedge mill is that mill stands have fixed diameter working and backup rolls. Diameter of working rolls at tandem stands is decreased, and diameters of backup rolls are increased in direction of rolling.

Horizontal axes of upper and lower rolls of the first three 
stands without screwdown mechanism in the proposed mill are shifted from the rolling axis vertically to the value $\Delta x_{i}=0,2 \cdot \boldsymbol{\Phi}_{n} \cdot D_{p} i_{i} \alpha_{i}{ }^{2}$, where $D_{p i}-$ diameter of new working rolls of $i$-stand, mm; $k_{\mathrm{\Pi}}$ - redressing index; $\alpha_{i}-$ admissible angle of rolling for rolls at $i$-stand.

Strips $200 \mathrm{~mm}$ long and $4 \times 150$ section $\mathrm{mm}$ of St 3 sp steel grade, cut but spark cutting out of hot-rolled plate as received were used for laboratory experiments. Those strips were heated in the furnace at $20^{\circ} \mathrm{C} / \mathrm{min}$ up to temperatures, given in the table 1, and were soaked within $30 \mathrm{~min}$. Overall time of soaking ( $\approx 40 \mathrm{~min}$ ) provided a full homogenization of austenite. Conditions of drafting and rolling temperature were modified during this experiment (Table 1). Temperatures were measured after reheating and when rolling by Testo 925 (Testo AG, Germany), one-channel temperature measurement device, high-perfomance and reliable thermocouple probes (Type $\mathrm{K}$ Thermocouple $(\mathrm{NiCr}-\mathrm{Ni})$ ). Temperature measurement range is from 50 to $+1100^{\circ} \mathrm{C}$. Inaccuracy: $-40 \ldots+900^{\circ} \mathrm{C}- \pm\left(0,5^{\circ} \mathrm{C}+0,3 \%\right.$ from the measured value), - $50 \ldots-40,+900 \ldots+1100^{\circ} \mathrm{C}-$ $\pm\left(0,7^{0} \mathrm{C}+0,5 \%\right.$ from the measured value $)$. Resolution: $0,1^{0} \mathrm{C}$ $\left(-50\right.$ до $\left.+199,9^{0} \mathrm{C}\right), 1^{0} \mathrm{C}$ (in another range of measurement).

Samples were cut out for structural investigation and assessment of mechanical properties after the experiment performance.
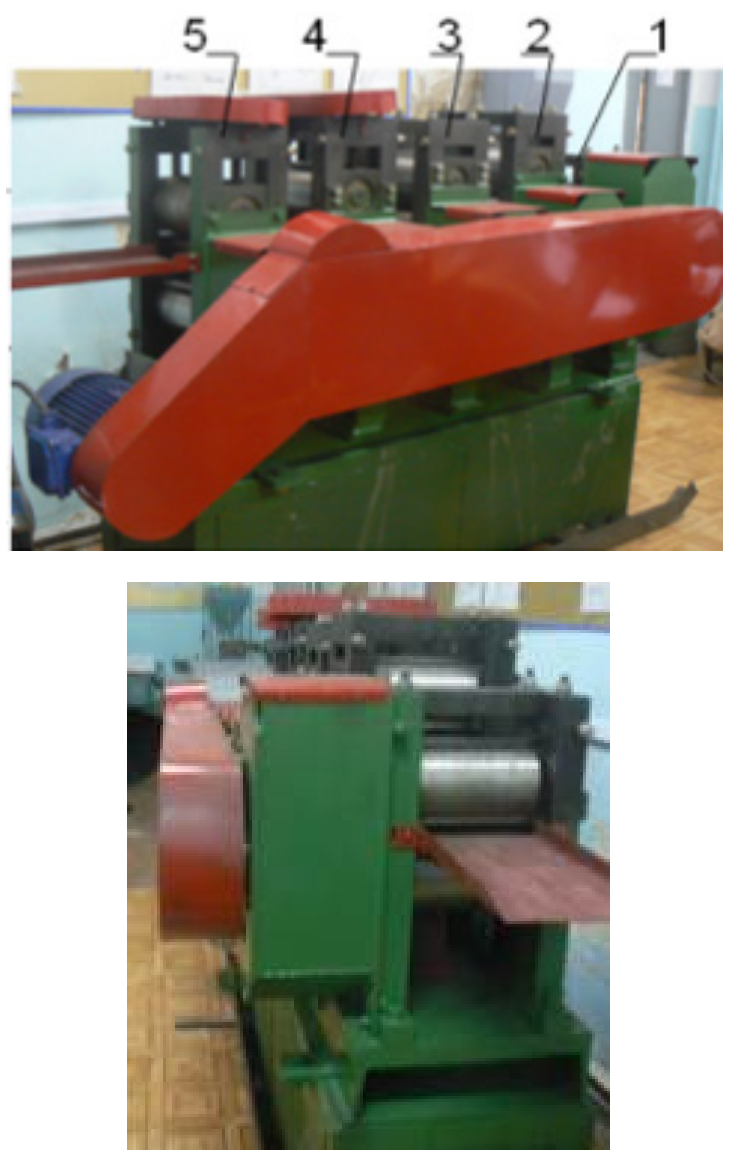

Figure 1. Five-stand longitudinal-wedge mill 1,2,3 - four-high stands without screwdown mechanism; 4, 5 - four-high stands with screwdown echanism
Table1. Experiment schedule

\begin{tabular}{|c|c|c|c|c|c|c|}
\hline \multirow{2}{*}{ Options } & \multirow{2}{*}{$\begin{array}{c}\text { Heating } \\
\text { temperature, }{ }^{\circ} \mathrm{C}\end{array}$} & \multicolumn{5}{|c|}{ Draft in the stand, \% } \\
\cline { 3 - 6 } & & №1 & №2 & №3 & №4 & №5 \\
\hline 1 & 1100 & 20 & 20 & 20 & 15 & 10 \\
2 & 1100 & 20 & 20 & 20 & 15 & 10 \\
3 & 1100 & 20 & 20 & 20 & 15 & 10 \\
4 & 1000 & 20 & 20 & 20 & 15 & 10 \\
5 & 1000 & 20 & 20 & 20 & 15 & 10 \\
6 & 1000 & 20 & 20 & 20 & 15 & 10 \\
7 & 950 & 20 & 20 & 20 & 15 & 10 \\
8 & 950 & 20 & 20 & 20 & 15 & 10 \\
9 & 950 & 20 & 20 & 20 & 15 & 10 \\
10 & 900 & 20 & 20 & 20 & 15 & 10 \\
11 & 900 & 20 & 20 & 20 & 15 & 10 \\
12 & 900 & 20 & 20 & 20 & 15 & 10 \\
\hline
\end{tabular}

Completion of table 1

\begin{tabular}{|c|c|c|c|}
\hline Options & $\begin{array}{c}\text { Air cooling } \\
\text { time, c }\end{array}$ & $\begin{array}{c}\text { Forced water } \\
\text { cooling time, } \mathrm{c}\end{array}$ & $\begin{array}{c}\text { Air cooling } \\
\text { time, } \mathrm{c}\end{array}$ \\
\hline 1 & 7 & 0 & 0 \\
2 & 2 & 3 & 2 \\
3 & 3 & 2 & 2 \\
4 & 7 & 0 & 0 \\
5 & 2 & 3 & 2 \\
6 & 3 & 2 & 2 \\
7 & 7 & 0 & 0 \\
8 & 2 & 3 & 2 \\
9 & 3 & 2 & 2 \\
10 & 7 & 0 & 0 \\
11 & 2 & 3 & 2 \\
12 & 3 & 2 & 2 \\
\hline
\end{tabular}

Carl Zeiss Axiovert-200 Mat light microscope was used for metallographic analysis with magnification at 200, 500 and 1000 vol. Software VideoTesT «Metal 1.0», as well as JNCA ENERGY energy-dispersive spectrometer (England) installed at JEOL electron probe microanalyzer at $25 \mathrm{kV}$ acceleration voltage were used for image processing. The range of JEOL is magnification from 40 to 40000 vol. Operation principle of microanalyzer is the following: high-powered ( $25 \mathrm{keV})$ sharp ( 1 micron) beam of electrons is directed at the sample, where it is transformed into raster (screenshot), scanning the sample. Upon that secondary electrons emitted by the sample are registered. The final pattern is very similar to the optical pictures but due to the fact that a beam of electrons is very sharp ( $\approx 1-2$ micron), the depth of focus is considerably higher, than optical pictures and magnification used is significantly higher, therefore, smaller structural components of the sample can be distinguished.

A quantitative analysis of defective substructure parameters and a phase-shift analysis were performed according to standard methods [3]. Disks for metallographic survey were traditionally prepared at grinding and polishing wheels. Concentrated solution of nitric acid in ethanol was used for samples pickling. Phase ratios of this sample were calculated on software VideoTest-Metal 1.0, on results of which diagrams of phase distribution at different temperatures were obtained.

Mechanical properties of St3sp steel were identified at 
MV-01m automated plant, permitting to perform mechanical tests at produced microdisks and promptly assess characteristics of the strength and flexibility without manufacturing of tension sample [4]. Experimentation was carried out at the device in the following way. Measurement head was installed in the low position. Polished section was installed at the lifting table and was pressed to its indenter head by rotating the table until contact of the ball with the surface of polished section. In this case load indicator is zero set. After this, «ISPYTAN DAT» catalog was input via PC and a read program and records of $\langle P-t\rangle$ and $\langle(\sigma-\delta\rangle$ array results registration were launched.

\section{Results and Discussion}

Research results of temperature distribution after rolling in each stand are given in the table 2, where is shown, that strip temperature is decreased passing from one stand to another, and rolling is completed in the last finishing stands in austenite and ferritic (option 4-9) or ferrite-pearlite (option 10-12) range with decrease of temperature.

Table 2. Temperature conditions of test rolling

\begin{tabular}{|c|c|c|c|c|c|}
\hline \multirow{2}{*}{$\begin{array}{c}\text { Heating } \\
\text { tempera } \\
\text { ture }\end{array}$} & \multicolumn{5}{|c|}{ Temperature of billet after rolling in the stand № $\left({ }^{\circ} \mathrm{C}\right)$} \\
\cline { 2 - 6 } & 1 & 2 & 3 & 4 & 5 \\
\hline $1100 \pm 6,4$ & $1062 \pm 5,3$ & $1037 \pm 5,4$ & $992 \pm 5,7$ & $983 \pm 6,8$ & $896 \pm 5,28$ \\
\hline $1100 \pm 5,6$ & $1074 \pm 5,4$ & $1053 \pm 5,8$ & $997 \pm 5,9$ & $984 \pm 6,3$ & $891 \pm 6,16$ \\
\hline $1100 \pm 5,8$ & $1068 \pm 3,7$ & $1048 \pm 3,92$ & $993 \pm 3,8$ & $976 \pm 3,43$ & $885 \pm 3,16$ \\
\hline $1000 \pm 6,1$ & $963 \pm 3,16$ & $923 \pm 3,27$ & $879 \pm 2,62$ & $869 \pm 2,58$ & $847 \pm 2,61$ \\
\hline $1000 \pm 5,6$ & $962 \pm 2,74$ & $919 \pm 2,62$ & $884 \pm 2,69$ & $859 \pm 2,92$ & $835 \pm 2,72$ \\
\hline $1000 \pm 5,2$ & $966 \pm 2,92$ & $926 \pm 2,91$ & $887 \pm 2,48$ & $861 \pm 2,82$ & $847 \pm 2,45$ \\
\hline $950 \pm 4,8$ & $919 \pm 2,83$ & $888 \pm 2,72$ & $867 \pm 2,29$ & $838 \pm 2,29$ & $803 \pm 2,63$ \\
\hline $950 \pm 4,9$ & $913 \pm 2,70$ & $883 \pm 2,65$ & $861 \pm 2,72$ & $827 \pm 2,73$ & $794 \pm 2,81$ \\
\hline $950 \pm 3,6$ & $918 \pm 2,29$ & $882 \pm 2,69$ & $857 \pm 2,83$ & $822 \pm 2,74$ & $791 \pm 2,48$ \\
\hline $900 \pm 3,1$ & $872 \pm 2,47$ & $858 \pm 2,39$ & $813 \pm 2,51$ & $791 \pm 2,43$ & $758 \pm 2,38$ \\
\hline $900 \pm 2,2$ & $871 \pm 2,44$ & $851 \pm 2,53$ & $818 \pm 2,42$ & $781 \pm 2,33$ & $738 \pm 2,41$ \\
\hline $900 \pm 2,8$ & $864 \pm 2,25$ & $838 \pm 2,82$ & $829 \pm 2,17$ & $784 \pm 2,48$ & $747 \pm 2,62$ \\
\hline
\end{tabular}

Completion of table 1

\begin{tabular}{|c|c|}
\hline Heating temperature & Strip temperature after cooling \\
\hline $1100 \pm 6,4$ & $862 \pm 4,8$ \\
\hline $1100 \pm 5,6$ & $717 \pm 3,63$ \\
\hline $1100 \pm 5,8$ & $742 \pm 2,59$ \\
\hline $1000 \pm 6,1$ & $828 \pm 3,49$ \\
\hline $1000 \pm 5,6$ & $616 \pm 2,46$ \\
\hline $1000 \pm 5,2$ & $648 \pm 3,27$ \\
\hline $950 \pm 4,8$ & $761 \pm 4,65$ \\
\hline $950 \pm 4,9$ & $547 \pm 2,52$ \\
\hline $950 \pm 3,6$ & $568 \pm 3,38$ \\
\hline $900 \pm 3,1$ & $726 \pm 2,49$ \\
\hline $900 \pm 2,2$ & $513 \pm 3,22$ \\
\hline $900 \pm 2,8$ & $528 \pm 2,51$ \\
\hline
\end{tabular}


Research of St3sp steel samples rolled according to options 1, 4, 7 and 10 and air cooled shown that:

- Strips rolled as per option 1, have a structure of large-size ferrite size $60-80$ micron, thick plate pearlite consisting of alternate plates of ferrite and cementite with an average interlamellar distance $\mathrm{n}=$ $0,8-0,98$ micron. Size of coarse pearlite groups reaches 62 - 90 micron (Figure 2,a);

- Rolling and cooling of strips according to option 4 causes structuring of lamellar pearlite with interlamellar distance $\mathrm{n}=0,52-0,73$ micron and size of groups $40-59$ micron. The structure consists of a small ferrite size $28-32$ micron, and surplus cementite $3-4$ points (figure 2, b);

- Structures of strips, strained and cooled according to options 7 and 10, have coarse paerlite with interlamellar distance $\mathrm{n}=0,72-0,91$ micron and size of groups $67-94$ micron, as well as ferrite banding size 43 - 135 micron and a surplus cementite with $2-3$ points (figure $3, a, b$ ).

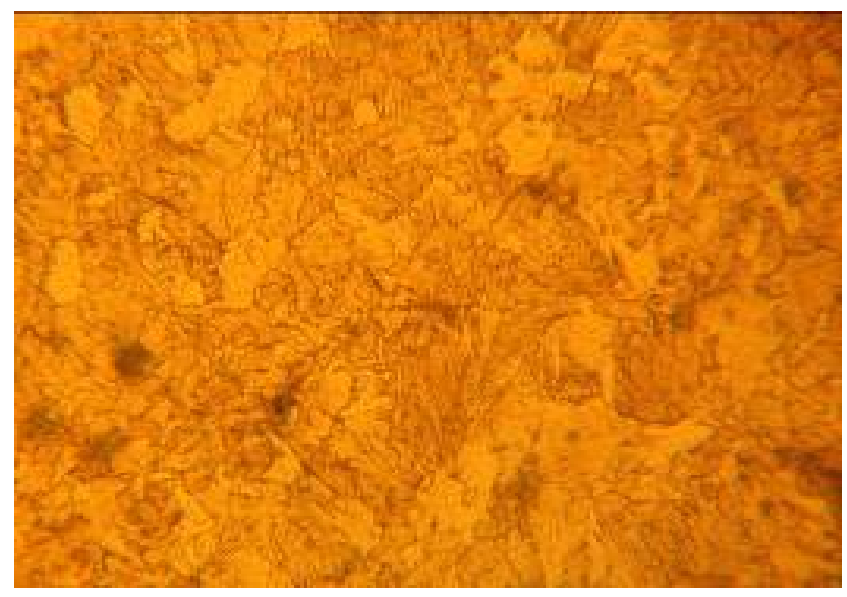

a)

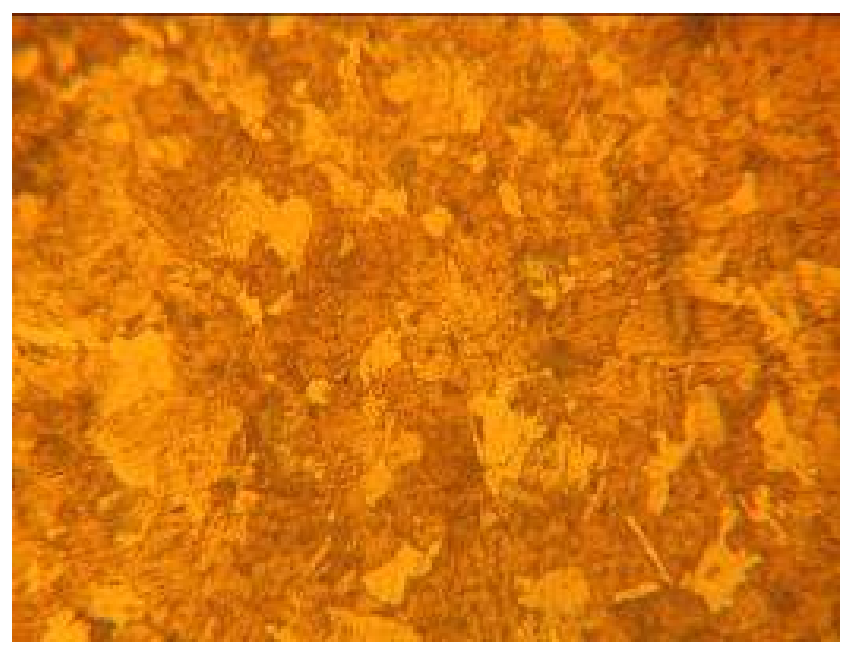

b)

Figure 2. Microstructure of Steel St3sp, laminated on options 1 (a) and 4 (b)

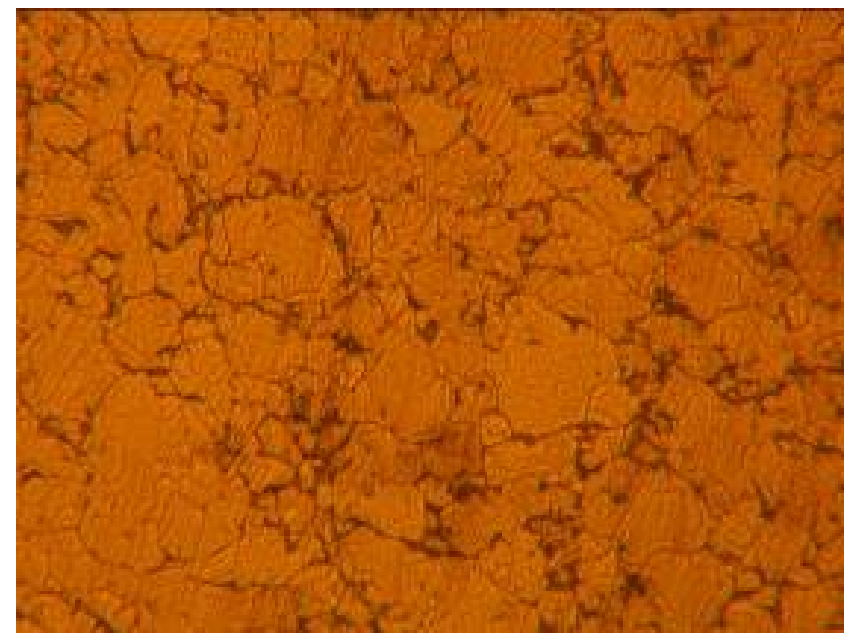

a)

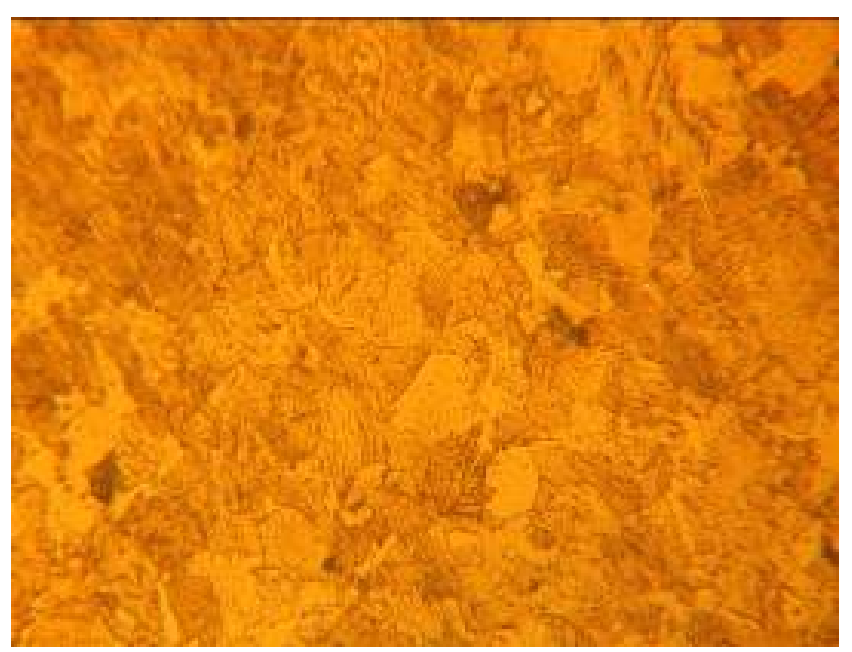

b)

Figure 3. The microstructure of steel St3sp, rolled on options 7 (a) and 10 (b)

Large-grained structuring when rolling and cooling according to option 1 can be explained by provision of conditions to pas a full primary recrystallization in the strained austenitic matrix when high-temperature rolling, as well as increase in austenite grain sizes at a high temperature. In fact, the larger size of the initial austenite grain, the larger heritable structure ferrite-pearlite.

Presence of large grains when rolling and cooling according to options 7 and 10 can be attributed to cold working gradient of austenite and ferrite grains along section of the strip at the lower strain temperature. When slow cooling recrystallization causes an enhanced growth of the grain along section in conditions of such gradation.

Fine-grained structuring when rolling and cooling of strips can be attributed to passing the primary recrystallization in austenite matrix and inheritance of fine-grained structure ferrite+paerlite by iron when slow cooling. However, value of cementite emissions meets 3-4 points what is irrational.

Upon completion of strips structure research, rolled according to conditions $2,3,5,6,8,9,11$ and 12 water and 
air cooled the following was established:

- After rolling and cooling as per options 2 and 3, due to full primary recrystallization in austenite matrix, as well as increase of austenite grain sizes at a high temperature, coarse-grain structure ferrite-paerlite size of grain $90-125$ micron is generated along section of the strip. Structure analysis shows that after cooling there spheroidation of paerlite, ferrite and surplus cementite, and the size of the emitted cementite are equal to 3-5 points (figure $4, a, b$ );

- Uniform fine-grain structure is obtained applying options 5 and 6 . Analyzed structures show that strips rolled and cooled as per options 5 and 6 have the structure ferrite+paerlite size $8-16$ micron. Decrease of strips temperature until $610-640^{\circ} \mathrm{C}$ in increased cooling of the strip at a temperature interval of the strong cementite emission (600 $\left.700^{\circ} \mathrm{C}\right)$ causes very small emissions of cementite $(2-$ 3 points) (figure $5, a, b$ );

- Structure analysis of strips rolled as per options $8-9$ indicates that rolling in austenite-ferrite range and air cooling causes fine paerlite generation with interlamellar $\mathrm{n}=0,23-0,33$ micron and size of groups $15-36$ micron. Small emissions of cementite (2-3 points) are evolved along ferrite grain boundaries at temperatures of enhance cooling completion $540-580^{\circ} \mathrm{C}$. The width of the band ferrite grains are irregular in shape with ill-defined boundaries and different sizes $(12-42 \mathrm{~m}$ ) (figure 6, a and b);

- Rolling temperature decrease in the last finishing stands up to temperature of ferrite-paerlite range (options 11 and 12), as well as subsequent air and water cooling cause fine paerlite with interlamellar distance $\mathrm{n}=0,13-0,24$ micron and sizes of groups $12-27$ micron. Besides, sizes of cementite are reduced (1-2 points) and ferrite is irregular shaped with ill-defined edges, as well as with different sizes (10 - 25 micron) (figure $7, a, b)$.

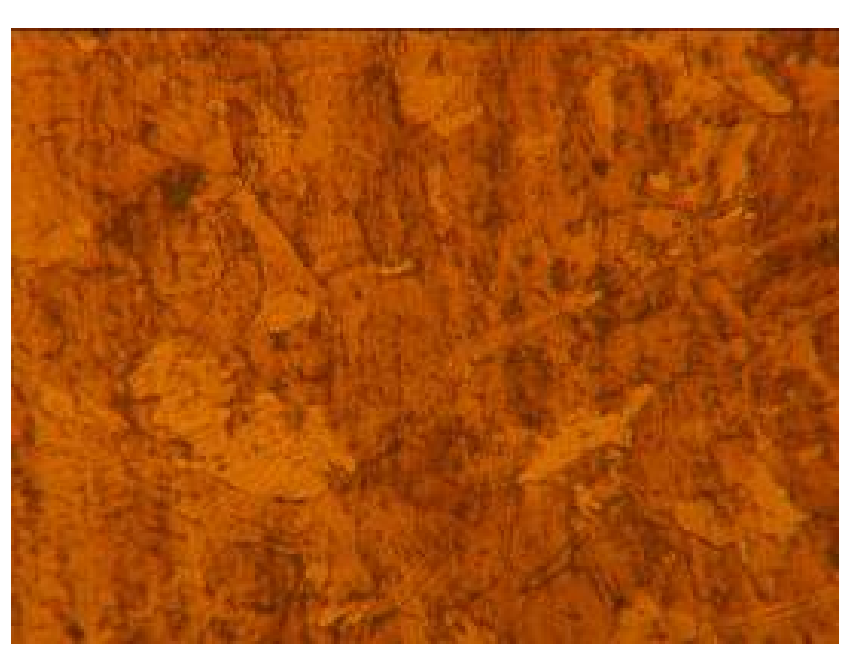

a)

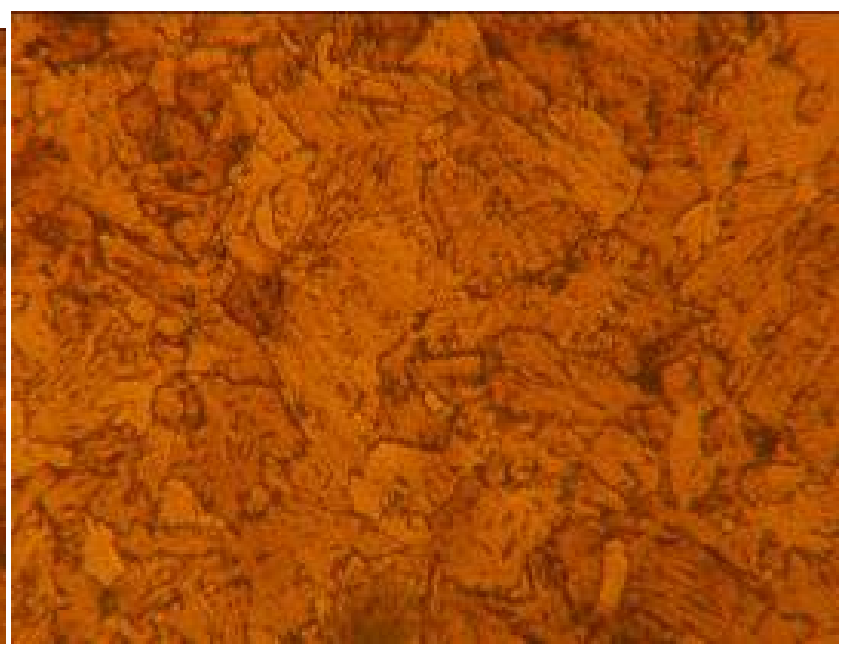

b)

Figure 4. Microstructure of Steel St3sp, laminated on two options (a) and 3 (b)

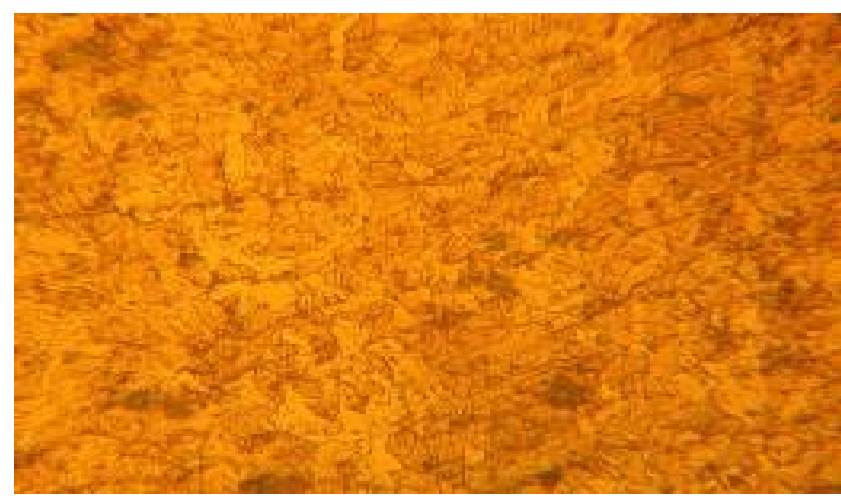

a)

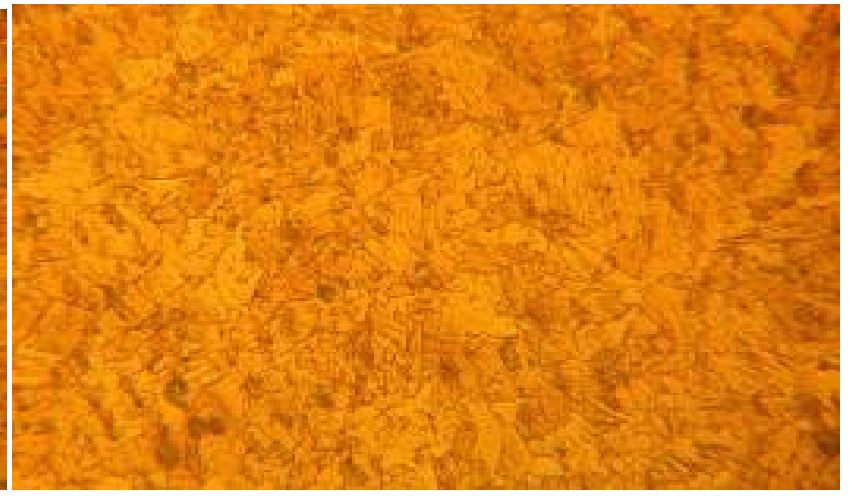

b)

Figure 5. The microstructure of steel St3sp, rolled on options 5 (a) and 6 (b) 
Upon research results of mechanical properties the following was established:

- After rolling at a high temperature (options 2 and 3) and slow cooling (options 1, 4, 7 and 10), surface of the strip has low values of yield point, ultimate resistance and hardness $(\mathrm{HB}=132,0-143,4 ; \mathrm{HRC}=$ $11,5-12,6 ; \mathrm{HV}=122,9-134,4 ; \mathrm{HRV}=62,5-66,4$; $\sigma_{0,2}=284,4-253,7 \mathrm{MPa} ; \sigma_{\mathrm{t}}=472,4-435,0 \mathrm{MPa} ; \delta_{\mathrm{p}}$ $=0,1602-0,1778$ );

- Mechanical properties without signs of widmanstatten pattern can be obtained at the surface of strips width $1,6 \mathrm{~mm}$, if to use rolling according to options 5 and $6(\mathrm{HB}=80,2-107,1 ; \mathrm{HRC}=6,5-9,0$; $\mathrm{HV}=71,8-98,1 ; \mathrm{HRV}=43,4-53,6 ; \sigma_{0,2}=127,6-$ $167,2 \mathrm{MPa} ; \sigma_{\mathrm{t}}=264,5-352,9 \mathrm{MPa} ; \delta_{\mathrm{p}}=0,2312-$ $0,3322)$;

- Mechanical properties of strips surface are with features of widmanstatten pattern at a low temperature of rolling and quenching (options 8,9 , 11 and 12) $(\mathrm{HB}=154,9-168,9 ; \mathrm{HRC}=13,8-15,3$; $\mathrm{HV}=160,4-146,1 ; \mathrm{HRV}=70,2-74,8 ; \sigma_{0,2}=316,6$ $-356,7 \mathrm{MPa} ; \sigma_{\mathrm{t}}=510,6-556,7 \mathrm{MPa} ; \delta_{\mathrm{p}}=0,1303-$ $0,1453)$.

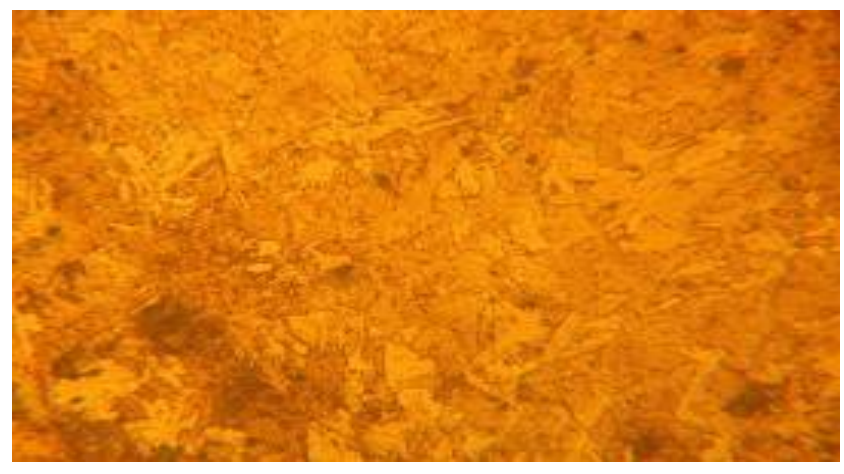

a)

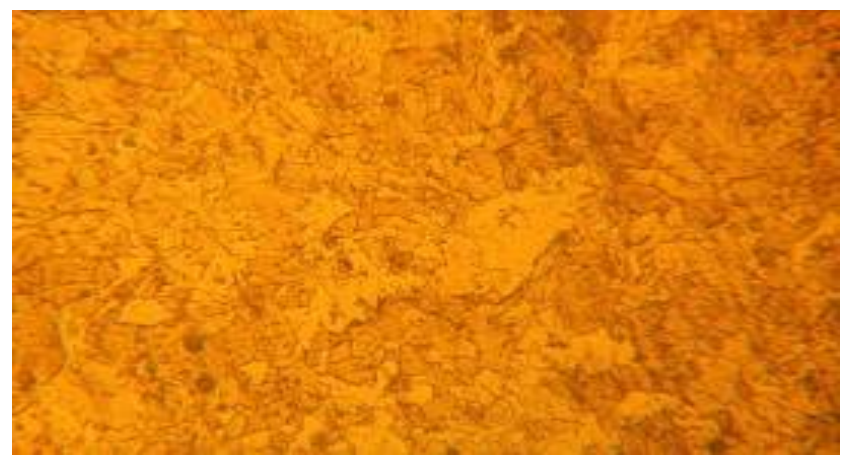

b)

Figure 6. The microstructure of steel St3sp, rolled on options 8 (a) and 9 (b)

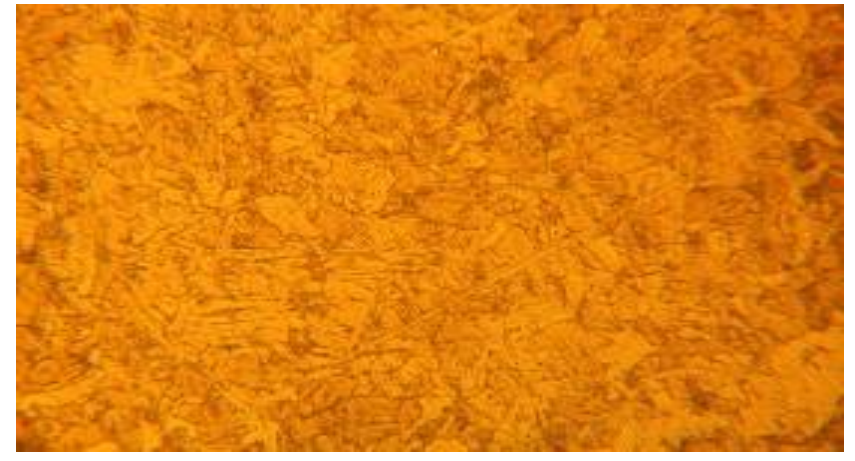

a)

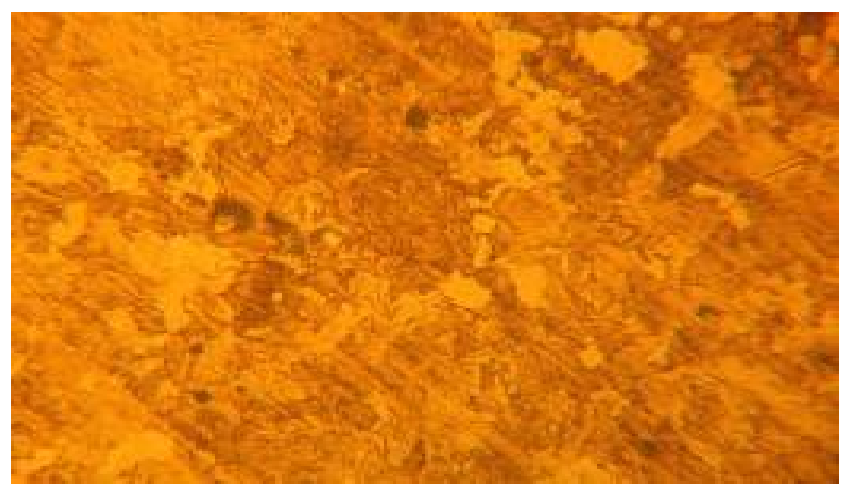

b)

Figure 7. The microstructure of steel St3sp, rolled on options 11 (a) and 12 (b)

\section{Conclusion}

1. To ensure mechanical properties and roll stock structure out of St3sp steel, rolling of strips shall be performed at finishing temperature $830-840^{\circ} \mathrm{C}$ and temperature of hot-rolled strips cooling $610-650^{\circ} \mathrm{C}$ at outgoing roller-way according to monotonous quenching and air cooling;

2. It is established that when austenite-ferrite and ferrite-paerlite rolling, ferrite is found as wrong elongated grains with ill-defined edges in microstructure of hot-rolled strips, where strips pattern has features of widmanstatten.

3. Grain of 10-11 points equiaxed through thickness of strips without widmanstatten features can be obtained at carbon steel strips thickness $1.6 \mathrm{~mm}$ when rolling and cooling according to options 5 and 6 ;

4. Uneven grain through thickness of strips is obtained at strips thickness $1.6 \mathrm{~mm}$ when rolling and cooling according to options 1, 2, 3 and 4 .

\section{REFERENCES}

[1] Barret R. Thin hot rolled strip chips away at cold rolled 
markets // Metal Bull. Mon. - 1999. - Apr., Suppl. - P. 25, 27-29.

[2] Innovative technologies for strip production / W. Bald, Q. Kneppe, D. Rosenthal, P. Sudau // Steel Times Int. -2000. 24. №5. - P.16-19.

[3] Degner M, Heller, T., P. Teza Rasrabotki V oblasti proisvodstva sverhtonkoi goryachekatanoi polosi // Chernie metalli. 2001. - №3 - p.24-26 (Developments in the field of production of ultrathin hot strip / / Ferrous metals.)

[4] Matsuoka S., Fumkiini O., Obara T. Process neprerivnoi goryachei prokatki tonkih stalnih polos // Netsu shori - J. Jap. Soc. Heat Treat. 1996. 36. Р. 299-304. (RM Metallurgy. 6Д70. 1997). (Process of continuous hot rolling of thin steel strips//Netsu shori - J. Jap. Soc. Heat Treat. 1996 . 36 . P. 299-304 . (RM Metallurgy. 6D70. 1997).)

[5] New developments of the company Danieli United for hot rolling of strip thickness less than $1.0 \mathrm{~mm}$ / / LFM. 1999. № 4. - p. 85-88.

[6] Flick F., Djumlija G. Conroll. Tehnologiya proizvodstva tonkoi goryachekatanoi poloci // Steel Times International. 1997. №3. P. 15 - 23 ((NChM. 1998, № 2. - pp. 50 - 61). (Flick F. Djumlija G. Conroll. Production technology of a thin hot-rolled strip//Steel Times International. 1997 . No. 3. P. 15 - 23 (NChM. 1998, No. 2. - Page 50 - 61).)

[7] Povishenie kachestva listovogo metalla /V.L. Mazur, A.P. Kachaylov, V.G. Ivanchenko, etc. - C.: Technology, 1979. 143 p. (Improving the quality of sheet metal/ V.L. Mazur, A.P.
Kachaylov, V.G. Ivanchenko, etc. - C.: Technology, 1979. 143 p.)

[8] Rudskoy A.I., Lunev V.A. Teoriya I technologiya prokatnogo proizvodstva: Uchebnoye possobiye. - SPb.: Nauka, 2005. 540 p. 377 il.

[9] Aldunin A.V. Osnovnie principi optimizacii processov goryachei prokatki polos po strukture i plastichnosti metalla// Izvestya visshih uchebnih zavedenii. Chernaya metallurgya, 2008. - No. 5. - Page 23-26. (The basic principles of optimization of processes of hot rolling of strips on structure and plasticity of metal// News of higher educational institutions. Ferrous metallurgy, 2008. - No. 5. - Page 23-26).

[10] Vibor tehnologicheskih rezhimov goryachei prokatki tonkih polos (Choice of technological modes of hot rolling of thin strips / V.L. Masur, L.A. Chmelev, V.A.Mazur, etc.//Steel, 1984. -№ 3. - Page 37-40.)

[11] Patent 20969. Continuous camp for the prorollers of bands from steels and alloys/ C.A.Mashekov, E.Z. Nugman, A.S. Mashekova etc.// publ. 16.03.2009, Bulletin №3.

[12] Electronic and microscopic researches of structural changes in steel 60GS2 at the fatigue / O.V.Sosnin, Yu.F. Ivanov, V.E. Gromov and other// Izvestya visshih uchebnih zavedenii. Chernaya metallurgya - 2004 . - No. 2. - Page 32-34.

[13] Matyunin V.M. Mekhanicheskiye i tekhnologicheskiye ispytaniya $i$ svoystva construktzionnykh materialov [Mechanical and process tests and properties of engineering materials]. - M.: MEI Publisher, 1996, 124 p. 